\title{
The potential for sand dams to increase the adaptive capacity of East African drylands to climate change
}

\author{
${\text { Catherine } \operatorname{Ryan}^{1,2} \cdot \text { Paul Elsner }}^{1}$
}

Received: 6 October 2015/Accepted: 14 February 2016/Published online: 14 March 2016

(C) The Author(s) 2016. This article is published with open access at Springerlink.com

\begin{abstract}
Drylands are home to more than two billion people and are characterised by frequent, severe droughts. Such extreme events are expected to be exacerbated in the near future by climate change. A potentially simple and cost-effective mitigation measure against drought periods is sand dams. This little-known technology aims to promote subsoil rainwater storage to support dryland agroecosystems. To date, there is little long-term empirical analysis that tests the effectiveness of this approach during droughts. This study addresses this shortcoming by utilising multi-year satellite imagery to monitor the effect of droughts at sand dam locations. A time series of satellite images was analysed to compare vegetation at sand dam sites and control sites over selected periods of drought, using the normalised difference vegetation index. The results show that vegetation biomass was consistently and significantly higher at sand dam sites during periods of extended droughts. It is also shown that vegetation at sand dam sites recovers more quickly from drought. The observed findings corroborate modelling-based research which identified related impacts on ground water, land cover, and socio-economic indicators. Using past periods of drought as an analogue to future climate change conditions, this study indicates that sand dams have potential to increase adaptive capacity and resilience to climate
\end{abstract}

Editor: Will Steffen.

Catherine Ryan

cate_is@yahoo.com

1 Department of Geography, Environment and Development Studies, Birkbeck, University of London, Malet Street, London WC1E 7HX, UK

221 Belvedere Court, London N1 5SL, UK change in drylands. It therefore can be concluded that sand dams enhance the resilience of marginal environments and increase the adaptive capacity of drylands. Sand dams can therefore be a promising adaptation response to the impacts of future climate change on drylands.

Keywords Normalised difference vegetation index . Climate change adaptation - Drylands - Sand dams . Remote sensing · Kenya

\section{Introduction}

Drylands cover more than $41 \%$ of the world's surface (Safriel and Adeel 2005), and they are home to 2.3 billion people, or nearly $30 \%$ of the world's population (UNDP 2014). Over one billion people from the developing world rely on dryland natural resources for their livelihoods (UNDP 2014).

Drylands are characterised by frequent, severe drought and climate extremes. Climate change is expected to increase the frequency and exacerbate the impacts of these, resulting in increased water scarcity. For most dryland regions, climate models predict higher temperatures, decreased precipitation, and an increase in intensity and frequency of extreme events such as droughts and heavy rainfall (Sörensen et al. 2008). Observational data suggests East African drylands are getting warmer with less rainfall, resulting in a drying effect that will increase with further climate change (Funk 2010). This threatens the ecosystems and people who depend on them, particularly agroecosystems where humans are heavily reliant on ecosystem resources for their livelihoods (Boko et al. 2007; Fischlin et al. 2007; Speranza 2012; Kilroy 2015). 
There is therefore an urgent need for appropriate and sustainable technologies that improve the ability of dryland communities and ecosystems to be resilient in the face of such challenges (Tucker et al. 2015).

In recent years the international community has turned its attention to adaptation responses to climate change (Boko et al. 2007; Schipper and Burton 2009). Sand dams are an example of such a potential response but are currently only promoted by a small number of national and international non-governmental organisations (NGO's). Sand dams are rain water harvesting structures which are already being used as a response to conditions of water scarcity in drylands. They are common to south-east Kenya only, and little systematic research has been done on them. However, the small number of studies that have been carried out suggest positive, sustainable, environmental and social impacts that could increase adaptive capacity to climate change conditions (Lasage et al. 2008; Pauw et al. 2008; Quilis et al. 2009).

It is timely to consider the usefulness of the wider application of sand dams as an appropriate technology for drylands in this policy environment. The first sand dam projects were implemented $>50$ years ago, with the majority built in the last 15 years, so there is now the opportunity to empirically test the effectiveness of sand dams during drought periods using remote sensing approaches. This paper describes such a research project. We will do this by first introducing the basic principles of the sand dam concept and contextualise its potential to improve climate change-related drought resilience. The methods section will then introduce data sources, the locations of case study dams and analytical approaches. This is then followed by a presentation of the results and a discussion of their significance for climate change adaptation and mitigation.

\section{Principles of the sand dam concept}

A sand dam is a reinforced concrete wall built across a seasonal riverbed to harvest rainwater (Fig. 1). Its objective is to support multiple uses, including water for human consumption, small-scale irrigation and livestock watering (Foster and Tuinhof 2004; Hut et al. 2008).

After construction, the first seasonal rains fill the dam area with water, silt and sand in both upstream and downstream directions. The coarser sand has the highest settling velocity and deposits upstream of the dam. The newly deposited sand provides additional water storage capacity. Suspended material with smaller grain sizes, such as silt, will wash over the top of the dam and continue downstream (Fig. 2). Sand dams are carefully designed so that the natural flow of the river is not altered, so as to avoid erosion downstream of the dam. For example, dams

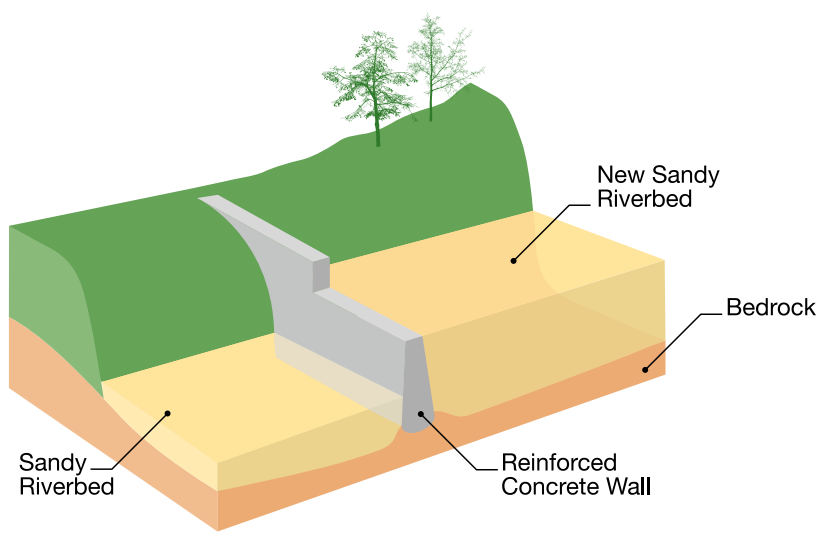

Fig. 1 Placement of a sand dam in a river bed. Source Excellent Development (2011)

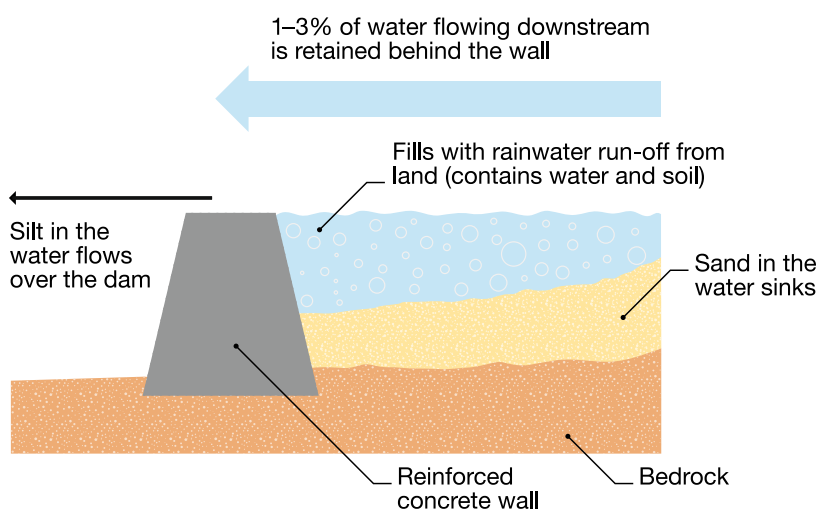

Fig. 2 Conceptual illustration of how a sand dam works. Source Excellent Development (2011)

are placed on long straight stretches of river rather than before a bend. A secondary spillway centres the water within the river bed and wing walls are built to keep the flood waters from going around the sand dam, causing erosion and eventually undercutting the dam walls.

Good land management practices accompany any sand dam build. Terracing and plantings occur in the catchment area to prevent run off, erosion and siltation. This is important because silt reduces the dams' ability to store water. Small rills or gullies are blocked to prevent soil erosion with plantings, sand bags or smaller sand dams (Maddrell and Neal 2012).

With each rainfall event, the size of the sand reservoir increases allowing more water to be stored. When mature, the dam comprises between 25 and $40 \%$ water (Maddrell and Neal 2012).

The dam also obstructs groundwater naturally flowing through the permeable riverbed. This creates higher upstream groundwater levels that subsequently infiltrate into the adjacent riverbanks, thus also raising groundwater levels in those riverbanks (Hoogmoed 2007). The 
subsurface groundwater flows and seasonal rains recharge the groundwater aquifer (Hoogmoed 2007). Water can then be extracted by the local population by using wells, pumps or scoop holes in the riverbed or banks upstream of the dam (Quilis et al. 2009).

The saturated sand material will also shield water from evaporation and contamination from animals. Additionally, sand acts as a natural slow filter, purifying the water and making it safer for humans to drink (Avis 2014).

\section{The potential for sand dams to increase adaptive capacity to climate change}

Adaptive capacity can be understood as the capability of a system to respond to climate variability by reducing vulnerability or enhancing resilience (Adger et al. 2007).

These two elements, vulnerability and resilience are further defined: vulnerability as the ability or inability of individuals and systems to respond to external stress placed on livelihoods (Kelly and Adger 2000); resilience as the capacity to absorb such disturbances so as to retain function, structure, identity and feedbacks (Walker et al. 2004).

In general, agro-ecosystems in the drylands of Africa have low adaptive capacity and high inherent exposure to climate change. Subsequently, subsistence farmers and ecosystems currently have low resilience to climate shocks such as droughts (Boko et al. 2007). Their high vulnerability is due to the reliance on rainfall for economic and social development. Makueni District in south-east Kenya is an example of such an agro-ecosystem. Makueni has experienced frequent and severe droughts in recent decades; such conditions are analogous to those projected under climate change (Christensen et al. 2007; Fischlin et al. 2007). Makueni has also experienced increasing population and population density since 1950, when it was barely inhabited. Before 1950, the dominant arid and semiarid areas served as extensive grazing grounds, but these areas are now permanent croplands (Speranza 2010) with an average population density in 2009 of 110 people per square km (Kenya National Bureau of Statistics 2013). The main issues facing the county are population growth $(1.4 \%$ per year), high levels of poverty $(64.3 \%)$, inadequate water supplies and population pressure on arable land affecting agricultural productivity (Republic of Kenya 2013). It is clear that anthropogenic pressures in the region have increased substantially in past decades, providing an added need for more sustainable water management that increases resilience to drought.

There is substantial concern that the adaptive capacity of the dryland pastoralists, smallholder and subsistence farmers may be overstretched by climate change, leading to increased poverty and unsustainable coping strategies (Sörensen et al. 2008). This is reflected by a renewed interest in ambitious schemes such as the Great Green Wall where large-scale tree planting means aims to reduce desertification in the Sahel region (O'Connor and Ford 2014). Smaller-scale technologies such as sand dams are an alternative way to increase resilience and decrease vulnerability of natural and human systems, and to increase their adaptive capacity (Boko et al. 2007; Adger et al. 2007). In south-east Kenya sand dams have proved to be relatively cheap and easy to build. Most of the cost is in construction, and thereafter they require low or no maintenance over their lifetime of 50 years or more. In Kenya the community provides much of the labour voluntarily, but siting expertise and coordination is provided by a handful of local NGO's. Steel and cement are bought in (Ertsen and Hut 2009). The average cost per $\mathrm{m}^{3}$ of water stored is around US\$1.15. (Akvopedia 2016). This makes them a cost-effective and accessible adaptation technology for the most vulnerable in society.

Vegetation plays an important role in drylands through valuable provisioning, regulating, supporting and cultural services to humans. Resilience to drought in drylands is key to the continuation of these services under climate change conditions. Hydro-geological models suggest sand dams are a way to increase groundwater due to a c. $40 \%$ increase of storage in riverbanks (Borst and de Haas 2006; Jansen 2007; Hoogmoed 2007). Moreover, modelling suggests the sand reservoir fills within days of the first rains, remaining through the season and river banks then fill within a month of the first rains. Groundwater is maintained throughout dry seasons and drought (Borst and de Haas 2006; Hut et al. 2008; Quilis et al. 2009) increasing the length of time communities have water reserves by up to 2.5 months (Pauw et al. 2008). These features enhance the resilience of vegetation to drought at sand dam sites.

Previous studies have not empirically demonstrated this enhanced resilience, but land cover change detection studies on the impact of sand dams go some way to validate modelling assumptions. Manzi and Kuria (2011) found that sand dams have a positive relation to land cover type; the presence of sand dams can create a shift in land cover from bare soils, before sand dams were built, to vegetated cover types afterwards. However, the study did not use control sites and the observed increase in vegetation may instead reflect the reported general greening in the region over the period studied (Conway et al. 2008).

The aim of this research is therefore to empirically test the hypothesis that sand dams increase the adaptive capacity of drylands by increasing the resilience of vegetation through times of water scarcity. This research tests the findings and assumptions from hydro-geological modelling studies (Borst and de Haas 2006; Hut et al. 2008; Quilis et al. 2009). A key indicator for this will be 
vegetation health, as it can be expected to improve at sand dam sites due to the additional water stored in sand dam reservoirs and riverbanks.

Vegetation growth is frequently limited by lack of water, thus the relative density of vegetation is a good indicator of drought (Weier and Herring 2000). Normalised difference vegetation index (NDVI) is the most commonly used index for vegetation density. Changes in vegetation can therefore be measured by differences in the NVDI calculated from satellite images. Furthermore, indications of the impact of sand dams on vulnerability can be identified from changes in NDVI.

Specific objectives for this study include:

1. to measure and compare vegetation at sand dam and control sites over selected periods of drought using NDVI;

2. to draw inferences from results on the impact of sand dams on vegetation in periods of water scarcity; and

3. to draw inference from results on the potential of sand dams as an adaptation response to climate change in drylands.

\section{Methods}

\section{Data}

The subhumid dryland valleys of the Makueni District in south-east Kenya were identified as the case study area (Fig. 3), where a number of sand dam projects have been implemented. Land in Makueni is classed as marginal for agricultural activities which are entirely rain fed (FAO 2000, cited in World Resources Institute 2012). Subsistence-oriented crop farming and livestock-keeping are the major livelihoods (Speranza 2010; Claessens et al. 2012). The district has a historical deficit of food supply compared to demand, and food production is low and fluctuates due to unreliable rainfall Kenya Food Security Meeting (2011).

The choice of sand dam sites was guided by the availability of information from local experts about their location, when they were built and how well they had been maintained. In the context of this project it was important that the dams were mature enough to have harvested rainfall in the study period, thus further confirmation was sought that that the dams were at least filled with water and partially filled with sand at the time in the periods of water scarcity studied. Additional confirmation was sought that land use changes had not affected the performance of sand dam sites from local NGO's (Cornelius, pers. comms. 2012; Stern, pers. comms. 2012). Given these criteria, four sample dams in the Nzyaa Valley were identified for selection.
Four control sites were identified for selection in the upper Kitandi valley, due to their similar conditions to the sample sites in the Nzaaya Valley, including a dry sub humid climatic zone (FAO 2005) and gentle slopes (1-3\% gradient). Soil types for both valleys are characterised as well drained upland soils with sandy clay to clay substrates. Both valleys have the same agro-climatic zone suitable for growing the same crops including maize, sorghum, beans, tomatoes, onions and sisal (Jaetzold et al. 2006). Local knowledge was sought to confirm that a similar amount of sand had accumulated in the riverbed as controls and that there were comparable land use patterns such as a lack of other sand dams - to avoid the potential positive impacts from sand dams on vegetation as described by Quilis et al. (2009), or the negative impacts of sand harvesting (Cornelius, pers. comms. 2012). For both sand dam and control sites a series of satellite images acquired by the U.S. Landsat programme were utilised. The Landsat programme is the longest running civilian space-born monitoring programme and provides a more than 40 year long time series of continuing global observation. Images were sourced from the United States Geological Survey sites; Earth Explorer and GLOVIS (United States Geological Survey 2012a, b). Data from these sites are freely available.

The images for this research project were collected by the thematic mapper (TM) sensor on-board the Landsat-5 satellite and the Enhanced Thematic Mapper (ETM+) sensor on-board Landsat-7. Both sensors provide spectral data from seven channels across the visible and infrared region of the electromagnetic spectrum (Markham and Helder 2012). The selected images had low cloud cover of less than $10 \%$. Their spatial resolution of $30 \mathrm{~m}$ made it possible to detect differences in vegetation at the relatively small scale of a sand dam, since their zone of influence is typically a small strip of 50-100 m wide (but up to $500 \mathrm{~m}$ ), and 200-300 m long (but up to $2 \mathrm{~km}$ ) either side of the river (Maddrell, pers. comms. 2012).

Ratios of band 3 (visible red light) and band 4 (nearinfrared) were used to convert the images to maps of the widely utilised normalised difference vegetation index (NDVI) (Carlson and Ripley 1997). This was then used to compare vegetation at sand dam and control sites using NDVI. Each Landsat image represented a different period in time between 2005 and 2012 when the region was experiencing drought. Differences in NDVI were compared using statistical methods including repeated-measures analysis of variance tests and $t$ tests.

Images captured three major periods of water scarcity in the study area between 2005 and 2006, 2008 and 2009, and late 2010 to 2012. The droughts of 2005-2006 and 2008-2009 were both recognised as severe (Johnson and Wambile 2011) and 2011 was recorded as one of the driest in 60 years after three consecutive seasons of poor rains 
Fig. 3 Study area-Makueni District in Kenya

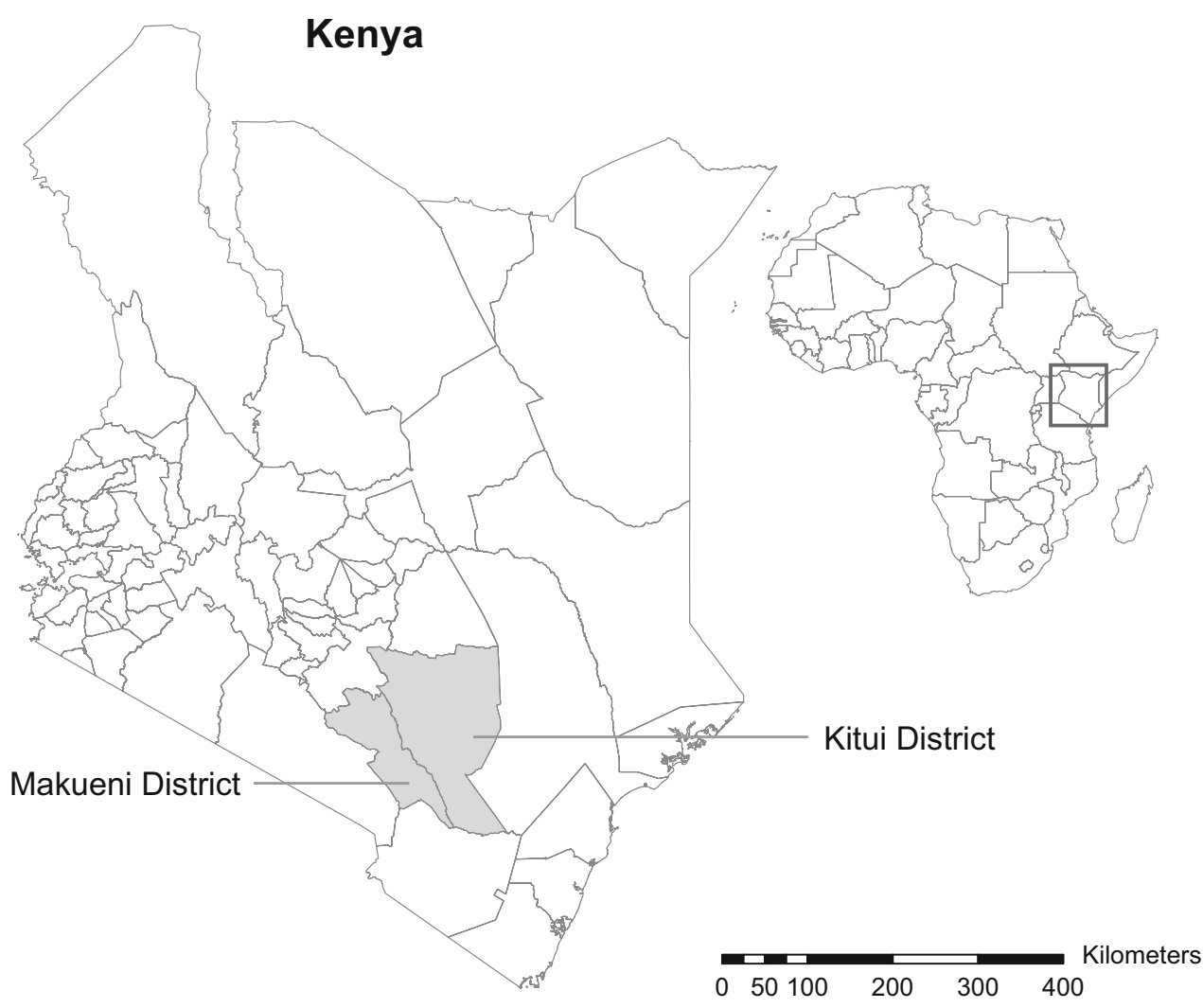

(FEWSNET 2011). Severe water scarcity continued into 2012. Information about weather conditions at the time that satellite images were taken was gathered from the famine early warning weather hazard reports archives (FEWSNET 2012a, b). These reports are at a district and regional level. Detailed and accurate local historical information, such as precipitation data, was not available at the study site level, since records for the closest weather stations did not include data for the sample period (FAO 2005, 2007).

In total 13 images covering sample and control sites were selected which provided 52 data points for samples from four sand dam sites and 52 for four control sites. Since 2003, Landsat 7 images have contained 'stripes' of missing data due to a known error with the scan line corrector and care was taken that none of the sand dam sites was affected by this data problem. Table 1 below lists the images used and attributes.

The zone of influence of a sand dam is reported to be up to a maximum of $2 \mathrm{~km}$ upstream of the dam and $500 \mathrm{~m}$ each side of the river (Maddrell, pers. comms. 2012). However, much of this area is often cultivated. In order to control for cropping, which could skew results, only the $25 \mathrm{~m}$ width of riparian strip adjacent to the riverbed was sampled since this area is generally left un-cropped (Neal, pers. comms. 2012). The riparian strip of the first $150 \mathrm{~m}$ upstream of sand dams was sampled, since that is where the effects of the dam are clearly observable. This means that on average a 2-3 pixel corridor of $150 \mathrm{~m}$ length was sampled each side of a river (i.e. 6 to 12 pixels per site).

For each image, the sample pixels were subsequently aggregated up to site level. To test the difference in mean NDVI values between sand dams and control sites, analysis of variance (ANOVA) tests were carried out. A repeatedmeasures ANOVA test (rANOVA) was selected as the most appropriate test for this analysis since it accounts for related measures (Field 2005). The use of a multivariate ANOVA test was not possible as the number of repeatedmeasures was high in comparison with the number of sites. The rANOVA treated sites as subjects and sample date as the repeated measure. In the case where analysis of a single date was required, a $t$ test was used to compare sand dam and control sites.

\section{Results}

\section{Highly significant difference across all samples}

Figure 4 below illustrates the mean NDVI values of sand dam and control sites for each satellite image. It can be seen that throughout the 7-year observation period, NDVI was consistently higher at sand dam sites.

Descriptive statistics for all samples are given at Table 2 below, which shows that the overall mean NDVI for sand 
Table 1 Satellite images selected for this study

\begin{tabular}{llll}
\hline Image number & Acquisition date & Sensor & Hydrological condition \\
\hline 1 & Jan 1, 2005 & Landsat 7 ETM+ & Relative greening \\
2 & Feb 2, 2005 & Landsat 7 ETM+ & Drought \\
3 & Oct 16, 2005 & Landsat 7 ETM+ & Drought \\
4 & Feb 21, 2006 & Landsat 7 ETM+ & Drought \\
5 & Oct 3, 2006 & Landsat 7 ETM+ & Drought \\
6 & Sept 6, 2008 & Landsat 7 ETM+ & Drought \\
7 & Jan 12, 2009 & Landsat 7 ETM+ & Extreme drought \\
8 & Sept 25, 2009 & Landsat 7 ETM+ & Drought \\
9 & Oct 30, 2010 & Landsat 7 ETM+ & Drought \\
10 & Dec 17, 2010 & Landsat 7 ETM+ & Drought \\
11 & Dec 25, 2010 & Landsat 7 ETM+ & Relative greening \\
12 & Jan 10, 2011 & Landsat 5 TM & Relative greening \\
13 & Feb 6, 2012 & Landsat 7 ETM+ & Drought \\
\hline
\end{tabular}

Fig. 4 Comparison of mean NDVI between 2005 and 2012. Periods of extreme drought are indicated by red shading, periods of drought by yellow shading and periods of relative greening by green shading

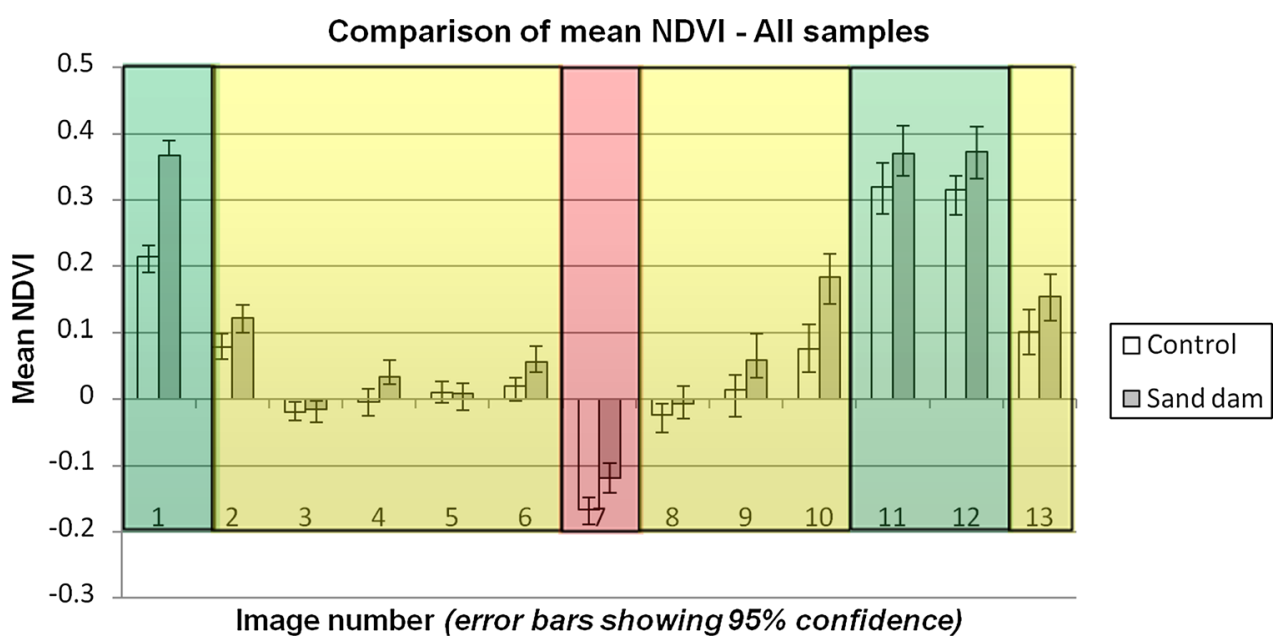

dam sites was 0.122 , compared to 0.072 at control sites. The overall treatment effect for all samples results in a highly significant statistical difference between mean NDVI values at sand dam sites compared to controls $(F=18.779, p=0.005)$.

\section{Results across different conditions of water scarcity}

To aid the further analysis of the relative performance of sand dam sites during periods of drought, three conditions of water scarcity and related NDVI response were defined

Table 2 Descriptive statistics for NDVI at sand dam versus control sites for all samples $(n=13)$

\begin{tabular}{lllll}
\hline Treatment & Mean NDVI & SE & \multicolumn{2}{c}{$95 \%$ Confidence interval } \\
\cline { 3 - 5 } & & & Lower bound & Upper bound \\
\hline Sand Dams & .122 & .008 & .102 & .142 \\
Controls & .072 & .008 & .052 & .092 \\
\hline
\end{tabular}

and the respective images grouped accordingly. These groupings are given at Table 1 and described below:

1. 'Drought' conditions: In this case mean NDVI values were less than the threshold for vegetated surfaces $(\mathrm{NDVI}=0.1)$, but greater than zero. Nine images fell under this category.

2. 'Extreme Drought' condition: In this case mean NDVI values were consistently negative. One image fell under this category.

3. 'Relative Greening': In this case mean NDVI values were greater than 0.2. Reports for Makueni District suggest that showers occurred around the dates the images in this category were acquired within the overarching periods of regional drought (FEWSNET 2012a, b; Kenya Food Security Steering Group 2011). Three images fell under this category (Table 1).

Table 3 below provides the NDVI values for each of these three different conditions of water scarcity: 
Table 3 Descriptive statistics for NVDI at sand dam and control sites in different conditions of water scarcity

\begin{tabular}{llllll}
\hline Hydrological condition & Treatment & Mean NDVI & SE & & \multicolumn{2}{l}{$95 \%$ Confidence interval } \\
\cline { 5 - 6 } & & & & Lower bound & Upper bound \\
\hline Drought & Sand Dams & 0.067 & 0.009 & 0.044 & 0.089 \\
& Controls & 0.029 & 0.009 & 0.006 & 0.051 \\
Extreme drought & Sand Dams & 0.118 & 0.011 & 0.154 & 0.082 \\
& Controls & 0.166 & 0.009 & 0.195 & 0.137 \\
Relative greening & Sand Dams & 0.370 & 0.010 & 0.346 & 0.394 \\
& Controls & 0.283 & 0.010 & 0.259 & 0.307 \\
\hline
\end{tabular}

During 'Drought' conditions, a significant difference between mean NDVI was observed at sand dam sites compared to controls $(F=8.766, P=0.025)$. The mean NDVI for sand dam sites during was 0.067 , compared to the mean NDVI for control sites is 0.029 (Table 3). This means that the NDVI at control sites was more than $50 \%$ lower compared to sand dam locations.

During the 'Extreme Drought' period, NDVI values were negative for both sand dam and control sites. Still, sand dam locations had a statistically significant higher NDVI values $(P=0.016)$ than control sites.

Under conditions of 'Relative Greening', NDVI values were sometimes an order of magnitude higher for both sand dam sites and controls compared to 'Drought' and 'Extreme Drought' conditions. A highly significant difference between mean NDVI values at sand dam sites compared to controls was found during these conditions $(F=38.780$, $P=0.001$ ). The mean value for sand dam sites was 0.370 , which typically represents healthy savannah or woodland vegetation, compared to 0.283 for controls (Table 3), which typically represents grass and shrubland (De Fries et al. 1995, 1998).

\section{Discussion}

The results of this research project demonstrate that sand dams substantially increased the ability of drylands to buffer extended periods of water scarcity. NDVI is a proxy for plant health, productivity, and biomass. A relative increase in NDVI at sand dam sites compared to non-sand dam indicates an improved resilience to adverse conditions. Mean NDVI at all sand dam sites was consistently significantly higher than at control sites during periods of water scarcity.

Even during 'Drought' and 'Extreme Drought' conditions, NDVI values at sand dam sites were consistently higher than controls. Although at times below the threshold for vegetated surfaces, sand dam sites were significantly less affected by drought than control sites. This was particularly evident even during the drought of 2008/2009 which was more severe and lasted longer than most droughts (International Livestock Research Institute 2010). The very low NDVI values for both sand dam and controls during this period are comparable to average values found by Anyamba and Tucker (2005), in a period of extreme drought across the Sahel 1983 to 1985.

It was also demonstrated that vegetation at sand dam sites recovered more quickly from drought. After showers occurred within a drought period, a 'Relative Greening' effect was more substantial at sand dam sites. Sand dam sites recovered to a mean NDVI of 0.37 , which is higher than the average long-term mean NDVI for the whole of the Kenyan Arid Lands region of 0.32 which includes both drought and non-drought periods between 2004 and 2009 (Johnson and Wambile 2011). This suggests sand dam sites are quickly elevated out of drought conditions after the precipitation. In comparison, sites without sand dams did not recover to this regional long-term average.

The NDVI responses corroborate findings from research on groundwater flows around sand dams, as the effects observed in this research are consistent with our understanding of groundwater flows around sand dams from previous research where sand dams increase groundwater storage in river banks by up to $40 \%$ which is maintained throughout the year (Borst and De Haas 2006; Jansen 2007; Hoogmoed 2007; Hut et al. 2008).

The increased groundwater storage means more soil moisture is available to plants. This is reflected by mean NDVI values that are consistently and significantly higher at sand dam sites than control sites in both drought and extreme drought cases and substantially higher over all cases. This feature of sand dams increases the resilience of agro-ecosystems by enabling vegetation to persist through drought disturbances.

Additionally, it is known that the aquifer is recharged with the first few days of precipitation (Borst and de Haas 2006; Hut et al. 2008). Moreover, the increased storage in the river bed extends laterally to the banks since river banks are considered to be important recharge areas for the groundwater stored upstream of the dam (Quilis et al. 2009), creating a positive effect on vegetation. This is reflected in the results for the 'Relative Greening' condition, where sand dam sites had above regional average 
mean NDVI values that elevated them out of drought conditions. This again increases resilience of agroecosystems by enabling them to recover more quickly from disturbance. Moreover, this feature of sand dams appears to have substantial potential to buffer the effects that climate change is expected to bring, such as more variable rainfall, with more frequent and intense floods (Sörensen et al. 2008)

Our research also suggests that sand dams increase the amount of vegetated land cover. NDVI is related to biomass and therefore land cover classes, or biome types (Tucker et al. 1985; De Fries et al. 1995, 1998). Consistently higher mean NDVI at sand dam sites supports the findings that sand dams increase the amount of vegetated land cover classes (Manzi and Kuria 2011). An increase in vegetated land cover types reduces vulnerability of exposure to both drought and floods, since land cover alters evaporation, runoff and ground water recharge, erosion and land degradation (Sahin and Hall 1996; DeFries and Eshleman 2004). Although greater replication of spatial and temporal samples is needed to accurately describe the impact of sand dams on biome types, these results are sufficiently robust that assumptions can be made about the direction of change and its application to net primary productivity.

Net primary productivity (NPP) has been shown to be well correlated with NDVI (Running et al. 2004). An increase in NDVI, and therefore NPP, reflects favourable growing conditions and an increase in biomass, which translates to an increase in potential yields and income for agro-ecosystems (Unganai and Kogan 1998). This could mean the difference between subsistence and surplus of provisions. With a surplus of provisions, communities are less vulnerable to the next drought, and so increasing their adaptive capacity. This is supported by findings that the average income of farmers increased in households with access to sand dams (Lasage et al. 2008; Pauw et al. 2008; Mutuku 2012). Moreover, food prices have been negatively related to NDVI anomalies in West Africa (Brown et al. 2006).

\section{Conclusions}

This study provides the first robust empirical quantification that sand dams have a substantial potential to mitigate drought events and addresses the need for more rigorous evidence base that can inform decision-making in climate change adaption (De Souza et al. 2015). Sand dam sites show consistently, statistically significantly higher mean NDVI throughout the 7-year observation period.

We also observed a buffering effect of sand dams due to a slower drying out of vegetation at sand dam sites at the onset of droughts, and faster, more sustained recovery after precipitation. These findings support the hypothesis that sand dams are an effective approach to increase the adaptive capacity of drylands by increasing the resilience of vegetation through times of water scarcity. Increased resilience increases the adaptive capacity of drylands to climate change. The satellite-based observations of this study agree well with the literature on modelled groundwater flows and storage around sand dams, as well as impacts on land cover and socio-economic indicators. It can therefore be concluded that the relatively simple sand dam technology is highly appropriate as an adaptation response to climate change in drylands. Due to their simple design and construction, sand dams are therefore a useful and cost-effective development approach. They also provide an interesting tool for mitigating the future effects of climate change.

Acknowledgments Acknowledgments go to the communities that built the sand dams in the study and for sharing information about them, including Makuta Mwea and Nzyaa Muiyso Self Help Groups. Sincere appreciation goes to the NGO's that gave their time and expertise in the preparation of this research including the Africa Sand Dam Foundation, Utooni Development Group and Excellent Development UK. Many thanks to Emma Newcombe and Steve GoreSmith for support.

Open Access This article is distributed under the terms of the Creative Commons Attribution 4.0 International License (http://crea tivecommons.org/licenses/by/4.0/), which permits unrestricted use, distribution, and reproduction in any medium, provided you give appropriate credit to the original author(s) and the source, provide a link to the Creative Commons license, and indicate if changes were made.

\section{References}

Adger WN, Agrawala S, Mirza MMQ, Conde C, O’Brien K, Pulhin J, Pulwarty R, Smit B, Takahashi K (2007) Assessment of adaptation practices, options, constraints and capacity. In: Parry ML, Canziani OF, Palutikof JP, van der Linden PJ, Hanson CE (eds) Climate change 2007: impacts, adaptation and vulnerability. Contribution of working group II to the fourth assessment report of the intergovernmental panel on climate change. Cambridge University Press, Cambridge

Akvopedia (2016) Sand dam. http://goo.gl/wChz61. Accessed 31 Jan 2016

Anyamba A, Tucker CJ (2005) Analysis of Sahelian vegetation dynamics using NOAA-AVHRR NDV data from 1981 to 2003. J Arid Environ 63:596-614. doi:10.1016/j.jaridenv.2005.03.007

Avis O (2014) A microbial analysis of water in Sand Dams and associated abstraction methods. Masters thesis, London School of Hygiene and Tropical Medicine

Boko M, Niang I, Nyong A, Vogel C, Githeko A, Medany M, OsmanElasha B, Tabo R, Yanda P (2007) Africa. In: Parry ML, Canziani OF, Palutikof JP, van der Linden PJ, Hanson CE (eds) Climate change 2007: impacts, adaptation and vulnerability. Contribution of working group II to the fourth assessment report of the intergovernmental panel on climate change. Cambridge University Press, Cambridge, pp 433-467 
Borst L, de Haas SA (2006) Hydrology of sand storage dams. A case study in the Kiindu catchment, Kitui District, Kenya. M.Sc. Thesis, Vrije Universiteit

Brown ME, Pinzon JE, Prince SD (2006) The effect of vegetation productivity on millet prices in the informal markets of Mali, Burkina Faso and Niger. Climatic Change 78(1):181-202. doi:10.1007/s10584-006-9096-4

Carlson TN, Ripley DA (1997) On the relation between NDVI, fractional vegetation cover and leaf area index. Remote Sens Environ 62:241-252. doi:10.1016/S0034-4257(97)00104-1

Christensen JH, Hewitson B, Busuioc A, Chen A, Gao X, Held I, Jones R, Kolli RK, Kwon WT, Laprise R, Magaña Rueda V, Mearns L, Menéndez CG, Räisänen J, Rinke A, Sarr A, Whetton P (2007) Regional climate projections. In: Solomon S, Qin D, Manning Z, Chen Z, Marquis M, Avery KB, Tignor M, Miller HL (eds) Climate change 2007: the physical science basis. Contribution of working group I to the fourth assessment report of the intergovernmental panel on climate change. Cambridge University Press, Cambridge

Claessens L, Antle JM, Stoorvogel JJ, Valdivia RO, Thornton PK, Herrero M (2012) A method for evaluating climate change adaptation strategies for small-scale farmers using survey, experimental and modeled data. Agric Syst 111:85-95. doi:10. 1016/j.agsy.2012.05.003

Conway D, Persechino A, Ardoin-Bardin S, Hamandawana H, Dickson M, Dieulin C, Mahe G (2008) Rainfall and water resources variability in sub-Saharan Africa during the 20th century, Norwich: Tyndall Centre Working Paper. http://www.tyndall.ac.uk/sites/ default/files/wp119.pdf. Accessed 01 Sept 2012

DeFries R, Eshleman KN (2004) Land-use change and hydrologic processes: a major focus for the future. Hydrol Process 18(11): 2183-2186. doi:10.1002/hyp.5584

De Fries R, Hansen M, Townshend J (1995) Global discrimination of land cover types from metrics derived from AVHRR pathfinder data. Remote Sens Environ 54:209-222. doi:10.1016/00344257(95)00142-5

De Fries RS, Hansen M, Townshend JRG, Sohlberg R (1998) Global land cover classifications at $8 \mathrm{~km}$ spatial resolution: the use of training data derived from Landsat imagery in decision tree classifiers. Int J Remote Sens 19(16):3141-3168. doi:10.1080/ 014311698214235

De Souza K, Kituyi E, Harvey B, Leone M, Murali KS, Ford JD (2015) Vulnerability to climate change in three hot spots in Africa and Asia: key issues for policy-relevant adaptation and resiliencebuilding research. Reg Environ Change 15(5):747-753. doi:10. 1007/s10113-015-0755-8

Ertsen M, Hut R (2009) Two waterfalls do not hear each other. Sandstorage dams, science and sustainable development in Kenya. Phys Chem Earth 34:14-22. doi:10.1016/j.pce.2008.03.009

Excellent Development (2011) Pioneers of Sand Dams. http://www. excellentdevelopment.com/site-assets/files/resources/publications/ pioneers-of-sand-dams.pdf. Accessed 07 Oct 2012

FEWSNET (2011) East Africa: past year one of the driest on record in the eastern Horn. USAID http://www.fews.net/docs/Publica tions/FEWS\%20NET\%20EA_Historical\%20drought\%20context_ 061411.pdf. Accessed 07 May 2012

FEWSNET (2012) East Africa, Kenya. Archive: drought and flood hazards assessment. USAID. http://www.fews.net/pages/coun tryarchive. $\operatorname{aspx}$ ?pid=300\&gb=ke\&l=en. Accessed 01 May 2012

FEWSNET (2012) Famine early warning system network. USAID. http://www.fews.net/pages/country.aspx?gb=ke\&l=en. Accessed 15 Apr 2012

Field A (2005) Discovering statistics with SPSS, 2nd edn. Sage Publications, London

Fischlin A, Midgley GF, Price JT, Leemans R, Gopal B, Turley C, Rounsevell MDA, Dube OP, Tarazona J, Velichko AA (2007)
Ecosystems, their properties, goods, and services. In: Parry ML, Canziani OF, Palutikof JP, van der Linden PJ, Hanson CE (eds) Climate change 2007: impacts, adaptation and vulnerability. Contribution of working group II to the fourth assessment report of the intergovernmental panel on climate change. Cambridge University Press, Cambridge, pp 211-272

Food and Agriculture Organisation (FAO) (2005) New_LocClim. Local Climate Estimator. http://www.fao.org/nr/climpag/pub/ en0201_en.asp. Accessed July-Sept 2012

Food and Agriculture Organisation (FAO) (2007) FAO Climpag. FAOClim-Net. http://geonetwork3.fao.org/climpag/agroclimdb_ en.php. Accessed July-Sept 2012

Foster S, Tuinhof A (2004) Sustainable groundwater management. Lessons from practice. Case Profile Collection Number 5. Brazil. http://siteresources.worldbank.org/INTWRD/Resources/ GWMATE_English_CP_05.pdf. Accessed 15 Sept 2012

Funk C (2010) A climate trend analysis of Kenya, Famine early warning systems network-informing climate change adaptation series. http://pubs.usgs.gov/fs/2010/3074/. Accessed 10 July 2012

Hoogmoed M (2007) Analyses of impacts of a sand storage dam on groundwater flow and storage. Groundwater flow modelling in Kitui District Kenya. MSc. Thesis, Vrije Universiteit

Hut R, Ertsen M, Joeman N, Vergeer N, Winsemius H, van de Giesen $\mathrm{N}$ (2008) Effects of sand storage dams on groundwater levels with examples from Kenya. Phys Chem Earth 33(1):56-66. doi:10.1016/j.pce.2007.04.006

International Livestock Research Institute (2010) An assessment of the response to the 2008-2009 drought in Kenya. A report to the European Union Delegation to the Republic of Kenya, Nairobi. http://eeas.europa.eu/delegations/kenya/documents/more_info/ assessment_of_the_response_2008_en.pdf. Accessed 27 Aug 2012

Jaetzold R, Schmidt H, Hornetz B, Shisanya C (2006) Farm Management Handbook of Kenya, Vol II, East Kenya, Eastern Province, 2nd edn. Ministry of agriculture, Nairobi

Jansen J (2007) The influence of sand dams on rainfall-runoff response and water availability in the semi-arid Kiindu catchment, Kitui District, Kenya. M.Sc. thesis, Vrije Universeit

Johnson N, Wambile A (eds) (2011) The impacts of the arid lands resource management project (ALRMPII) on livelihoods and vulnerability in the Arid and Semi-Arid Lands of Kenya. ILRI Research Report 25, Nairobi. http://www.ilri.org/ilrinews/index. php/archives/tag/alrmpii. Accessed 21 Apr 2012

Kelly PM, Adger WN (2000) Theory and practice in assessing vulnerability to climate change and facilitating adaption. Clim Change 47(4):325-352

Kenya Food Security Steering Group (2011) The 2011 long rains season assessment report. Government of Kenya. http://home. wfp.org/stellent/groups/public/documents/ena/wfp240180.pdf. Accessed 16 Aug 2015

Kenya National Bureau of Statistics (2013) Statistical Abstract 2013. http://www.knbs.or.ke/index.php?option=com_phocadownload\& view $=$ category $\& i d=106 \&$ Itemid $=1177$. Accessed 03 Jan 2016

Kilroy $G$ (2015) A review of the biophysical impacts of climate change in three hotspot regions in Africa and Asia. Reg Environ Change 15(5):771-782. doi:10.1007/s10113-014-0709-6

Lasage R, Aerts J, Mutiso GCM, De Vries A (2008) Potential for community based adaptation to droughts: Sand Dams in Kitui, Kenya. Phys Chem Earth 33(1-2):67-73. doi:10.1016/j.pce. 2007.04.009

Maddrell S, Neal I (2012) Sand dams: a practical guide. Excellent Development, London. http://www.excellentdevelopment.com/ resources/publications. Accessed 15 Sept 2012

Manzi H, Kuria D (2011) The use of satellite images to monitor the effect of sand dams on stream bank land cover changes in Kitui District. J Agric Sci Technol 13(2):133-150 
Markham BL, Helder DL (2012) Forty-year calibrated record of earth-reflected radiance from Landsat: a review. Remote Sens Environ 122:30-40. doi:10.1016/j.rse.2011.06.026

Mutuku NB (2012) Impact of Sand Dams on social economic status of the local inhabitants. A case of Kitui Central Division, Kenya. LAP LAMBERT Academic Publishing, Saarbrücken

O'Connor D, Ford J (2014) Increasing the effectiveness of the "Great Green Wall" as an adaptation to the effects of climate change and desertification in the Sahel. Sustainability 6(10):7142-7154. doi:10.3390/su6107142

Pauw WP, Mutiso S, Mutiso G, Manzi HK, Lasage R, Aerts JCJH (2008) An Assessment of the social and economic effects of the Kitui Sand Dams community based adaptation to climate change, SASOL Foundation and IVM Institute for Environmental studies Vrije University, Amsterdam. http://dare.ubvu.vu.nl/ bitstream/1871/20935/2/R-08-08.pdf. Accessed 21 Aug 2012

Quilis RO, Hoogmoed M, Ertsen M, Foppen JW, Hut R, de Vries A (2009) Measuring and modeling hydrological processes of sandstorage dams on different spatial scales. Phys Chem Earth 34:289-298. doi:10.1016/j.pce.2008.06.057

Republic of Kenya (2013) Makueni County First County Integrated Development Plan 2013-2017. http://www.makueni.go.ke/sites/ default/files/documents/MAKUENI\%20CIDP\%205TH\%20APRIL $\% 202014$.compressed.pdf. Accessed 03 Jan 2016

Running SW, Nemani RR, Heinsch FA, Zhao M, Reeves M, Hashimotoa H (2004) Continuous satellite-derived measure of global terrestrial primary production. Bioscience 54(6):547-560. doi:10.1641/0006-3568(2004)054[0547:acsmog]2.0.co;2

Safriel U, Adeel Z (2005) Dryland systems, Chapter 22, pp. 623-662 In: Hassan R, Scholes R, Ash N (eds) Ecosystems and human well-being: current state and trends. The millennium ecosystem assessment, Vol. 1. Island Press, Washington. http://www. maweb.org/documents/document.291.aspx.pdf. Accessed 04 Aug 2012

Sahin V, Hall MJ (1996) The effects of afforestation and deforestation on water yields. J Hydrol 178:293-309. doi:10.1016/00221694(95)02825-0

Schipper ELF, Burton I (2009) The Earthscan reader on adaptation to climate change. Earthscan, London

Sörensen L, Trx A, Duchrow A (2008) Sustainable land management in drylands - challenges for adaptation to climate change. In:
Kamotho S, Strahm W, Wolfangel C (eds) The nature of drylands, diverse ecosystems, diverse solutions. IUCN World Conservation Congress Barcelona 2008. http://data.iucn.org/ dbtw-wpd/edocs/2008-023.pdf. Accessed 10 July 2012

Speranza CI (2010) Drought coping and adaptation strategies: understanding adaptations to climate change in agro-pastoral livestock production in Makueni, District, Kenya. Eur J Dev Res 22(5):623-642. doi:10.1057/ejdr.2010.39

Speranza CI (2012) Buffer capacity: capturing a dimension of resilience to climate change in African smallholder agriculture. Reg Environ Change 13(3):521-535. doi:10.1007/s10113-0120391-5

Tucker CJ, Townshend JRG, Goff TE (1985) African land-cover classification using satellite data. Sci New Ser 227(4685):369-375. doi:10.1126/science.227.4685.369

Tucker J, Daoud M, Oates N, Few R, Conway D, Mtisi S, Matheson S (2015) Social vulnerability in three high-poverty climate change hot spots: what does the climate change literature tell us? Reg Environ Change 15(5):783-800. doi:10.1007/s10113-014-0741-6

UNDP (2014) Environment and energy, drylands development centre, where we work. http://web.undp.org/drylands/a-where.html. Accessed 19 Jan 2014

Unganai LS, Kogan FN (1998) Drought monitoring and corn yield estimation in Southern Africa from AVHRR data. Remote Sens Environ 63(3):219-232. doi:10.1016/S0034-4257(97)00132-6

United States Geological Survey (2012a) Earth Explorer. http:// earthexplorer.usgs.gov/. Accessed Feb-Sept 2012

United States Geological Survey (2012b) USGS global visualisation viewer. http://glovis.usgs.gov/ Accessed Feb-Sept 2012

Walker B, Holling CS, Carpenter SR, Kinzig A (2004) Resilience, adaptability and transformability in social-ecological systems. Ecol Soc 9(2):5

Weier J, Herring D (2000) Measuring Vegetation (NDVI and EVI), Nasa Earth Observatory. http://earthobservatory.nasa.gov/Fea tures/MeasuringVegetation/printall.php. Accessed 28 Aug 2012

World Resources Institute (2012) Drylands, people, and ecosystem goods and services: a web-based geospatial analysis http://www. wri.org/publication/drylands-people-and-ecosystem-goods-andservices. Accessed 10 July 2012 